\title{
PEMANFAATAN LIMBAH SAGU (METROXYLON SAGO) SEBAGAI BAHAN DASAR PAKAN TERNAK UNGGAS
}

\author{
Haedar $^{1}$, Jumawan Jasman ${ }^{2}$ \\ Sekolah Tinggi Ilmu Ekonomi Muhammadiyah Palopo \\ ${ }^{1}$ E_Mail: haedar.stiemplp@gmail.com
}

\begin{abstract}
Pengembangan usaha ternak harus didukung dengan pengembangan industri pakan melalui optimalisasi pemanfaatan sumber-sumber bahan baku lokal spesifik lokasi dan berorientasi pada pola integrasi tanaman-ternak. Pakan di daerah tropis kebanyakan bermutu rendah dengan serat kasaryang tinggi. Keadaan ini merupakan tantangan bagi sub sektor peternakan, karena perlu mencari pakan alternatif untuk meningkatkan produksi ternak. Fungsi mahasiswa sangat strategis dalam mewujudkan kondisi yang dihadapi oleh masyarakat pedesaan. Sinergi antara mahasiswa yang sedang melaksanakan Kuliah Kerja Nyata (KKN)memberikan informasi sekaligus mempraktikan temuan-temuan baru yang diperoleh di bangku Perguruan Tinggi. Potensi bahan baku lokal berupa limbah pertanian, perkebunan dan agroindustri sangat besar, namun hanya sebagian kecil yang digunakan sebagai pakan. Jumlah limbah yang banyak tersebut, sampai saat ini belum dimanfaatkan sebagaimana mestinya hanya dibiarkan menumpuk pada tempat-tempat pengolahan tepung sagu sehingga menyebabkan pencemaran lingkungan. Oleh karena itu, dibutuhkan strategi pemberdayaan dan pembinaan yang meliputi introduksi teknologi, penata laksanaan budidaya, manajemen pakan yang akan memanfaatkan limbah ampas sagu yang sangat berlimpah dengan masyarakat sasaran bekerjasama Kwarda Hisbul Watan dan Pemuda Karang Taruna Kota Palopo. Program KKN-PPM yang dilaksanakan menghasilkan luaran berupa (1) Metode Rencana Bisnis untuk pengembangan Usaha Pakan Ternak ayam buras dan itik; (2) Teknologi tepat guna dalam pemanfaatan Limbah ampas sagu; (3) Terjadi transfer ilmu pengetahuan dan teknologi;(4) Produk berupa Pakan ternak komersil skala industri kecil.
\end{abstract}

Keywords: Limbah Ampas Sagu, Metroxylon Sago, Fermentasi, Pakan, Ternak

\section{PENDAHULUAN}

Sagu (Metroxylon sago Rottb.) merupakan tanaman asli Indonesia dan diyakini berasal dari Danau Sentani, Kabupaten Jayapura, Papua dan tersebar di kepulauan Sumatera, Kalimantan dan Sulawesi (Lokakarya Sagu, 2007). Luas perkebunan sagu diperkirakan 1,2 juta ha dan di Riau berkisar antara 69.916 ha (Azaly, 2008). Sagu memiliki beberapa potensi, yakni sebagai sumber pangan dan bahan industri (Lokakarya Sagu, 2007). Sebagai sumber pangan sagu dapat diolah menjadi berbagai macam makanan yang dapat dikonsumsi oleh masyarakat. Sedangkan sebagai sumber bahan industri sagu dapat diolah menjadi tepung. Dari tepung sagu dapat dibuat bahan perekat dan plastik karena mudah terurai secara alami (biodegradable). Peningkatan jumlah produksi sagu berbanding lurus dengan peningkatan jumlah limbah yang dihasilkan. Limbah yang berasal dari pengolahan sagu terbagi menjadi limbah padat, cair, dan gas. Limbah berbentuk padat dan cair belum diolah secara maksimal dan masih menggunakan sistem sederhana yang langsun dialirkan ke dalam sungai yang mengalir di sekitar kawasan kilang sagu. Hal ini dapat menyebabkan pencemaran disekitar sungai tersebut bahkan mengakibatkan kedangkalan sungai

Indonesia adalah negara yang memiliki areal tanaman sagu (Metroxylon sp.) terbesar di dunia hingga 1,2 juta ha. Di Indonesia luas areal tanaman sagu mencapai 1.128 .000 ha atau 51,3\% dari 2.201.000 ha areal sagu di dunia (Deptan, 2004). 
Sagu merupakan salah satu sumber daya alam nabati di Indonesia yang mulai akhir tahun 70-an semakin meningkat pemanfaatannya sebagai akibat dari program pemanfaatan swasembada pangan nasional. Potensi lestari produksi sagu sebesar 5.000.000 ton per tahun, namun yang baru dimanfaatkan sebesar 200.000 ton per tahun.

Pada pengolahan sagu terdapat limbah atau hasil ikutan yang berupa kulit batang dan ampas. Ampas yang dihasilkan dari proses ekstraksi ini sekitar $14 \%$ dari total berat basah batang sagu (Flach, 1997). Di sentra-sentra produksi, limbah ampas sagu pada umumnya belum dimanfaatkan dan ditumpuk begitu saja yang pada akhirnya akan mencemari lingkungan (Kompiang, 1995).

Ampas sagu (Metroxylon sago) merupakan limbah yang dihasilkan dari pengolahan sagu, dimana dalam proses tersebut diperoleh tepung dan ampas sagu dalam perbandingan $1: 6$, yang kaya akan karbohidrat dan bahan organik lainnya. Ampas yang dihasilkan dari proses extraksi ini sekitar $14 \%$ dari total berat basah batang sagu (Flach, 1997 dan Rumalatu, 1981). Jumlah limbah yang banyak tersebut, sampai saat ini belum dimanfaatkan sebagaimana mestinya hanya dibiarkan menumpuk pada tempat - tempat pengolahan tepung sagu sehingga menyebabkan pencemaran lingkungan. Kalaupun ada ternak yang memanfaatkannya, hanya ternak-ternak yang berada di sekitar lokasi pengolahan tepung sagu, yang langsung mengkonsumsi di tempat penumpukan ampas tanpa dikontrol.

Potensi bahan baku lokal berupa limbah pertanian, perkebunan dan agroindustri sangat besar, namun hanya sebagian kecil yang digunakan sebagai pakan. Masih banyak jenis limbah pertanian, perkebunan \& agroindustri yang belum dimanfaatkan. Teknologi pakan lengkap (completefeed) merupakan salah satu metoda/teknik pembuatan pakan yang digunakan untuk meningkatkan pemanfaatan limbah pertanian atau perkebunan dan limbah agroindustri melalui proses pengolahan dengan perlakuan fisik dan suplementasi untuk produksi pakan ternak unggas.

Salah satu kendala yang dihadapi oleh usaha peternakan adalah belum tercukupinya kebutuhan nutrisi terutama protein dan nutrisi pakan, sehingga ternak belum dapat tumbuh dan berkembang dengan baik. Pakan di daerah tropis kebanyakan bermutu rendah dengan serat kasar yang tinggi. Keadaan ini merupakan tantangan bagi sub sektor peternakan, karena perlu mencari pakan alternatif untuk meningkatkan produksi ternak.

Identifikasi beberapa Permasalahan di masyarakat pedesaan khususnya Kelurahan Pentojongan Kecamatan Telluwanua yaitu:

1. Lemahnya pengetahuan teknis masyarakat petani sagu di pedesaan mengenai potensi nilai ekonomis limbah ampas sagu.

2. Perlunya penyeliaan dan transfer teknologi bagaimana proses mengupayakan limbah ampas sagu yang berlimpah menjadi bahan dasar pakan ternak yang memiliki nilai ekonomis tinggi.

3. Perlunya pelatihan mengenai penatalaksanaan pengelolaan usaha pengolahan limbah ampas sagu sebagai bahan dasar pakan ternak unggas dan ruminansia. 
Perlunya pemberian pendampingan bagaimana cara usaha dalam membuat produk baru hingga manajemen pasca produksinya.

Target yang hendak dicapai melalui Program KKN-PPM di Kelurahan Pentojangan Kecamatan Telluwanua ini adalah:

1. Masyarakat kelurahan dan mitra termotivasi untuk berwirausaha dalam melahirkan produk baru dengan sumber bahan baku yang tersedia melimpah karena memiliki bekal keterampilan dan ilmu dalam mengolah dan memanfaatkan limbah ampas sagu yang selama ini hanya menjadi limbah dan sumber pencemaran lingkungan.

2. Terjadi penyerapan tenaga kerja dan pengurangan angka pengangguran di pedesaan sehingga mampu menekan angka urbanisasi.

3. Meningkatkan keberdayaan ekonomi dan kesejahteraan masyarakat Kelurahan Pentojangan.

\begin{tabular}{l}
\hline METODE DAN BAHAN \\
Dari permasalahan yang dihadapi \\
masyarakat di Kelurahan Pentojangan mengenai \\
permasalahan limbah ampas sagu, yang dalam hal \\
ini khususnya akan di Kelurahan Pentojangan \\
Kecamatan Telluwanua Kota Palopo, maka solusi \\
yang ditawarkan dalam program KKN-PPM ini \\
akan diarahkan untuk: \\
1. Memecahkan masalah yang ada dengan \\
menyelenggarakan pelatihan teknis \\
pembuatan pakan ternak dengan \\
menggunakan bahan dasar limbah ampas \\
sagu yang selama ini belum termanfaatkan.
\end{tabular}

2. Pengenalan teknologi tepat guna untuk melakukan pemrosesan limbah ampas sagu berupa mesin pencacah untuk memotong, mengecilkan ukuran dan membuat seragam limbah yang ada.

3. Praktek melakukan fermentasi limbah ampas sagu yang sudah dilakukan perlakuan khusus.

4. Memberikan dan melakukan pendampingan dalam usaha agroindustri pembuatan pakan ternak kepada petani bekerjasama dengan mitra, baik pada aspek teknis, manajemen hingga pasca produksi dan manajemen pemesaran produknya.

\section{Kebijakan/ Konsep yang akan digunakan. Teknologi Silase untuk pembuatan pakan ternak Ruminansia.}

Limbah pengolahan sagu termasuk kategori limbah basah (wet by-products) karena masih mengandung kadar air $70-80 \%$, sehingga dapat rusak dengan cepat apabila tidak segera diproses. Perlakuan melalui pengeringan membutuhkan biaya yang relatif tinggi sehingga perlu dikembangkan melalui teknologi alternatif lain agar produk tersebut dapat dimanfaatkan secara lebih efisien. Teknologi silase adalah suatu proses fermentasi mikroba merubah pakan menjadi meningkat kandungan nutrisinya (protein dan energi) dan disukai ternak karena rasanya relatif manis. Silase merupakan proses mempertahankan kesegaran bahan pakan dengan kandungan bahan kering $30-35 \%$ dan proses ensilase ini biasanya dalam silo atau dalam lobang tanah, atau wadah lain yang prinsipnya harus pada kondisi anaerob (hampa udara), agar mikroba anaerob dapat melakukan reaksi fermentasi (Sapienza dan Bolsen, 1993). 
Keberhasilan pembuatan silase berarti memaksimalkan kandungan nutrien yang dapat diawetkan. Selain bahan kering, kandungan gula bahan juga merupakan faktor penting bagi perkembangan bakteri pembentuk asam laktat selama proses fermentasi (Khan et al., 2004) Pada fase awal proses ensilase, enzim yang bekerja dalam proses respirasi pada bahan mengoksidasi karbohidrat yang terlarut, menghasilkan panas dan menggunakan gulagula yang seyogyanya siap pakai untuk proses fermentasi. Kehilangan gula pada proses respirasi merupakan hal yang menyulitkan baik dari sudut pandang pengawetan melalui proses pembuatan silase maupun dari segi nilai nutrisinya. Gula merupakan substrat bagi bakteri penghasil asam laktat yang akan menghasilkan asam yang berfungsi sebagai pengawet bahan yang disilase tersebut.

Tahap awal pembuatan silase adalah melakukan pencacahan ampas sagu dengan menggunakan mesin pencacah, kemudian melakukan pengurangan kadar air ampas sagu (menggunakan panas matahari) selama $\pm 6-8$ jam tergantung intensitas sinar matahari sehingga kadar air limbah sagu tersebut berkisar $50-55 \%$, kemudian diproses menjadi silase melalui cara dicampur dengan bahan aditif yaitu molases/ gula tetes $15 \%$ untuk merangsang aktivitas mikroba dalam proses fermentasi pembuatan silase, serta untuk meningkatkan kandungan energi dan protein silase yang dihasilkan nantinya. Setelah dicampur merata dimasukkan ke dalam kantong (dua lapis) dengan ukuran $50 \mathrm{~kg}$, dipadatkan untuk meminimumkan udara (proses fermentasi anaerob). Kemudian disimpan ditempat teduh (bebas sinar matahari) selama \pm 3 minggu tergantung cepat lambatnya proses silase. Setelah 3 minggu diambil sampel silase ampas sagu sebanyak 500 gram untuk dianalisis kandungan nutriennya (Kiston et al., 2011)

Bahan penyusun konsentrat adalah dedak halus, jagung giling, bungkil kelapa, urea, tepung ikan, tepung tulang, ultramineral dan garam. Konsentrat ketiga perlakuan pakan memiliki kandungan energi dan protein yang berbeda, sehingga setelah diketahui kandungan nutrisi silase limbah sagu maka setiap perlakuan pakan diupayakan memiliki kandungan energy (DE 2,8 $\mathrm{kkal} / \mathrm{kg}$ ) dan protein (16\%)

\section{Teknologi Fermentasi Untuk Pembuatan Pakan Ternak Unggas}

Yang membedakan penggunaan teknologi ini dengan yang pertama adalah bentuk pakan ternak yang dihasilkan yang mana pada penggunaan teknologi dengan proses yang pertama pakan akan limbah akan dibiarkan basah dan di jaga untuk tetap dalam keadaan segar. Metode yang kedua adalah ditujukan untuk memperoleh hasil pakan yang dapat diawetkan berbentuk kering yang cocok untuk pemberian ransum pakan jenis unggas. Faktor keterbatasan potensi penggunaan limbah ampas sagu sebagai pakan ternak unggas adalah karena kandungan protein kasarnya rendah dan memiliki serat kasar tinggi. Untuk mendapatkan pakan yang kaya akan kandungan protein dan vitamin pada limbah ampas sagu maka Ampas sagu diolah dengan menggunakan teknologi fermentasi.

Teknologi fermentasi ini untuk meningkatkan kadar protein ampas sagu hgga 14\%. Adapun prosedur dan teknik fermentasi ampas sagu sama denngan prosedur Fermentasi 
yang sudah lazim. Tahapan fermentasi limbah ampas sagu ini adalah:

1. Limbah ampas sagu terlebih dahulu di masukan dalam mesin pencacah untuk mengecilkan ukurannya, kemudian langkah selanjutnya ampas sagu yang telah dicacah di jemur sampai kering, selanjutnya diayak untuk memisahkan tepung elasagu dari serat.

2. Tepung ampas sagu kering dibasahi sampai lembab (basah), lalu dilakukan pengukusan selama 30 menit atau sampai terasa lengket.

3. Ampas sagu yang telah dikukus/ matang dibiarkan hingga dingin betul, kemudian di timbang dan ditambahkan urea sebanyak 3\% dari berat ela sagu basah kemudian diaduk hingga merata, lalu tambahkan Aspergillus niger (dapat menggunakan ragi tape) sebanyak 3-5 gram/kg ela sagu, kemudian campurkan hingga homogen.

4. Ampas sagu yang telah diberikan ragi (Aspegillus niger) ditempatkan dalam wadah yang bersih, bebas air dan minyak, kemudian tutup rapat hingga antara 48-72 jam kemudian baru dibuka.

5. Ampas sagu yang telah mengalami fermentasi sempurna memiliki ciri-ciri sebagai berikut: aromanya tercium sangat khas buah atau beraroma seperti tape ketan, warnanya aga kemerahan, teksturnya lembut dan rasanya agak manis. Hasil fermentasi kemudian dijemur (atau menggunakan mesin pengering) sampai kering dan siap di kemas atau digunakan dalam sebagai rangsum pakan unggas.

Proses fermentasi mempunyai kelebihan antara lain tidak memiliki efek samping yang negatif, mudah dilakukan, relatif tidak membutuhkan peralatan khusus dan biaya relatif murah sehingga masyarakat dan petani mitra KKN-PPM di Kelurahan Pentojangan Kecamatan Telluawanua Palopo mampu mempratikannya tanpa menghadapi kendala yang berarti.

\section{HASIL DAN PEMB AHASAN}

Pelaksanaan program KKN-PPM dalam kegiatan pemanfaatan limbah ampas sagu (Metroxylon Sagu) di Kelurahan Pentojangan Kecamatan Telluwanua berupa pelatihan dan pendampingan pada aspek teknis pembuatan pakan ternak dengan bahan dasar ampas sagu.

Seluruh peserta yang terlibat dalam program KKN-PPM diberikan pembekalan sebelum diterjunkan pada lokasi KKN-PPM.

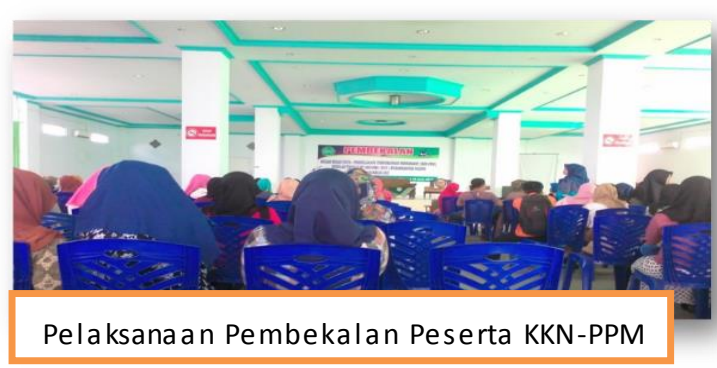

Mekanisme pelaksanaan kegiatan pemberdayaan Masyarakat terhadap pemanfaatan limbah ampas sagu. Materi persiapan dan pembekalan KKN-PPM yang diberikan kepada mahasiswa adalah sebagai berikut:

1. Pelatihan pembuatan pakan ternak yang meliputi;

$\rightarrow$ Identifikasi bahan baku (Ampas sagu) yang baik dan masih layak untuk di proses lebih lanjut menjadi bahan dasar pembuatan pakan ternak. 
$\rightarrow$ Perlakuan terhadap bahan sebelum menggunakan teknologi silase dan fermentasi.

$\rightarrow$ Analisis studi kelayakan bisnis pakan ternak dengan bahan baku ampas sagu.

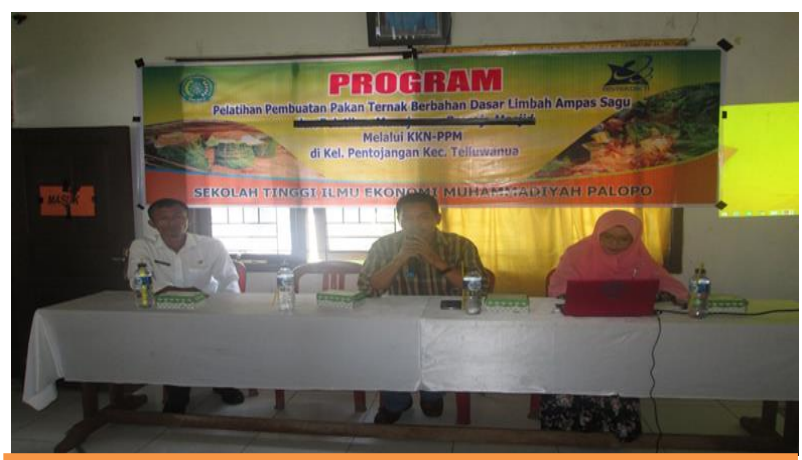

Penyelenggaraan Pelatihan pada Pelaksanaan Kegiatan KKN-PPM

2. Manajemen dan tatalaksana usaha pembuatan pakan ternak berbahan dasar ampas sagu.

3. Motivasi usaha dan menumbuhkan jiwa Entrepreneurship

4. Manajemen pasca produksi, packaging dan pemasaran produk

5. Teknik-teknik pemberdayaan dan penyuluhan masyarakat.

Pelaksanaan kegiatan KKN-PPM dengan merujuk pada Volume Jam Kerja Efektif Mahasiswa sebagai nberikut:

\begin{tabular}{|c|c|c|c|c|}
\hline No. & Nama Program & Kegiatan & Volume & \begin{tabular}{|l} 
Volume \\
GKEMD
\end{tabular} \\
\hline 1. & $\begin{array}{l}\text { Sosialisasi } \\
\text { Program KKN- } \\
\text { PPM }\end{array}$ & 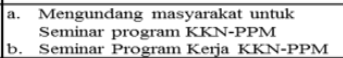 & $\begin{array}{r}8 \times 2 \mathrm{jam} \\
30 \times 2 \mathrm{jam}\end{array}$ & $\begin{array}{l}16 \\
60\end{array}$ \\
\hline 2. & $\begin{array}{l}\text { Penyiapan Sarana } \\
\text { dan Prasarana }\end{array}$ & \begin{tabular}{|ll} 
a. & Rapat koordinasi persiapan \\
b. & Pembentukan kepengurusan \\
c. & Pembangunan dan penyiapan \\
d. & fasilitas \\
d. Pembuatan tungku pemasak
\end{tabular} & $\begin{array}{r}30 \times 2 \mathrm{jam} \\
5 \times 2 \mathrm{jam} \\
5 \times 8 \mathrm{jam} \\
3 \times 8 \mathrm{jam}\end{array}$ & $\begin{array}{l}60 \\
10 \\
40 \\
24\end{array}$ \\
\hline 3. & $\begin{array}{l}\begin{array}{l}\text { Penyiapan } \\
\text { peralatan dan } \\
\text { introduksi } \\
\text { peralatan }\end{array} \\
\end{array}$ & $\begin{array}{l}\text { a. Pengadaan peralatan (ayakan, sekop, } \\
\text { Terpal, timbangan, Drum plastik), } \\
\text { mesin pencacah. } \\
\text { b. Pengadaan Ampas sagu, ragi tape, } \\
\text { URFA }\end{array}$ & $3 \times 8 \times 3$ lokasi & 72 \\
\hline 4. & $\begin{array}{l}\text { Peningkatan } \\
\text { pengetahuan dan } \\
\text { keterampilan } \\
\text { teknis (pembuatan } \\
\text { pakan dan } \\
\text { manajemen pakan) } \\
\text { (pelatihan) }\end{array}$ & 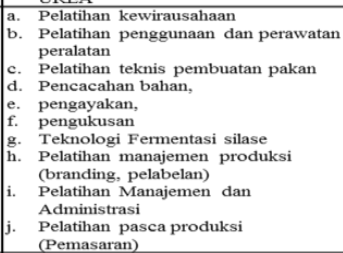 & $\begin{array}{l}6 \times 2 \mathrm{jam} \\
5 \times 2 \mathrm{jam} \\
5 \times 3 \mathrm{jam} \\
6 \times 3 \mathrm{jam} \\
6 \times 2 \mathrm{jam} \\
6 \times 3 \mathrm{jam} \\
6 \times 2 \mathrm{jam} \\
6 \times 2 \mathrm{jam} \\
6 \times 2 \mathrm{jam}\end{array}$ & $\begin{array}{l}10 \\
10 \\
15 \\
18 \\
12 \\
18 \\
12 \\
12 \\
12 \\
12\end{array}$ \\
\hline 5. & $\begin{array}{l}\text { Praktik kerja } \\
\text { (Pembuatan Pakan } \\
\text { Ruminansia } \\
\text { metode teknologi } \\
\text { silase) }\end{array}$ & $\begin{array}{l}\text { a. Pencacahan bahan } \\
\text { b. Pencapuran bahan aditif } \\
\text { c. Penjemuran bahan hasil ayakan } \\
\text { d. Proses ensilase } \\
\text { e. pendinginan, } \\
\text { f. pengepakan }\end{array}$ & $\begin{array}{r}6 \times 8 \mathrm{jam} \\
6 \times 8 \mathrm{jam} \\
10 \times 12 \mathrm{jam} \\
7 \times 3 \times 24 \mathrm{jam} \\
6 \times 24 \mathrm{jam} \\
6 \times 8 \mathrm{jam}\end{array}$ & $\begin{array}{l}22 \\
24 \\
120 \\
504 \\
144 \\
72\end{array}$ \\
\hline 6. & \begin{tabular}{|l} 
Praktik kerja \\
(Pembuatan \\
Pembuatan pakan \\
ternak unggas \\
teknologi \\
fermentasi)
\end{tabular} & $\begin{array}{l}\text { a. Pencacahan bahan } \\
\text { b. Penisahan dan pengayakan } \\
\text { c. Penjemuran bahan hasil ayakan } \\
\text { d. Pengukusan } \\
\text { e. } \\
\text { f. fermentasi bahan, } \\
\text { g. pendinginan, } \\
\text { g. pengepakan }\end{array}$ & $\begin{array}{r}6 \times 8 \mathrm{jam} \\
6 \times 8 \mathrm{jam} \\
10 \times 12 \mathrm{jam} \\
30 \times 30 \mathrm{menit} \\
6 \times 72 \times 2 \mathrm{jam} \\
6 \times 24 \mathrm{jam} \\
6 \times 8 \mathrm{jam}\end{array}$ & $\begin{array}{l}24 \\
24 \\
120 \\
15 \\
864 \\
144 \\
48\end{array}$ \\
\hline 7. & $\begin{array}{l}\text { Monitoring dan } \\
\text { evaluasi kegiatan }\end{array}$ & $\begin{array}{l}\text { a. Pendampingan dan pembimbingan } \\
\text { b. Konsultasi (coaching klinik) }\end{array}$ & $\begin{array}{r}3 \times 42 \mathrm{jam} \\
1 \times 42 \times 2 \mathrm{Jam}\end{array}$ & $\begin{array}{l}406 \\
84\end{array}$ \\
\hline & am Kerja Efe & & JKEM & 144 \\
\hline
\end{tabular}

\section{Pelaksanaan Kegiatan KKN-PPM}

Pemberdayaan Pemanfaatan Limbah Ampas Sagu (Metroxylon Sagu) Sebagai Bahan Dasar Pakan Ternak Unggas Di Kelurahan Mancani Palopo, Sulawesi Selatan, tahapan kegiatan

- Pembentukan kelompok dengan pendekatan partisipatif PRA dengan melibatkan kelompok Mitra sasaran, tokoh masyarakat, dan perangkat desa. Kelompok dibentuk dari, oleh dan untuk kepentingan para anggota kelompok itu sendiri. Dengan cara berkelompok akan tumbuh kekuatan gerak dari para anggota dengan prinsip keserasian, kebersamaan dan kepemimpinan dari mereka sendiri.

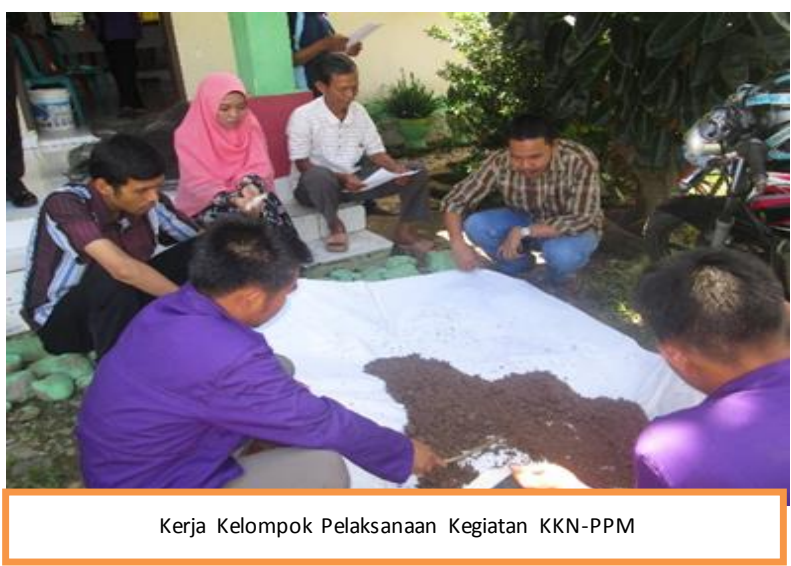

- Penguatan kerjasama kelompok Mitra dan mahasiswa dilakukan untuk meningkatkan kemampuan dalam melakukan proses produksi limbah menjadi pakan ternak.

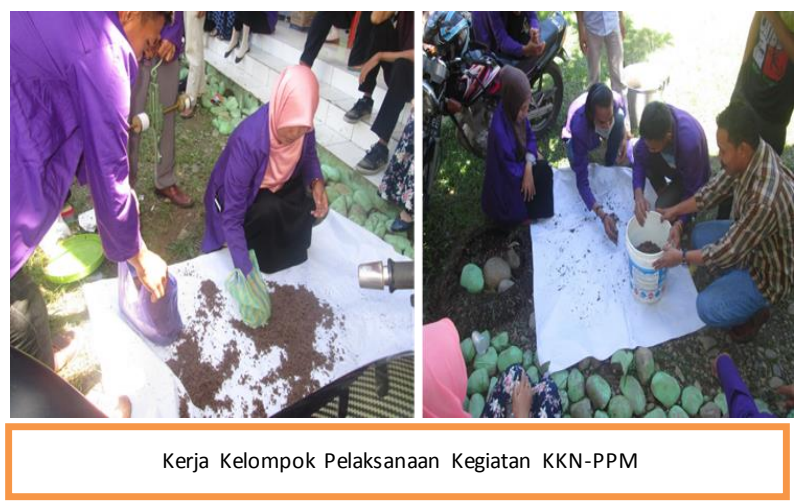


- Pelatihan: pelatihan dilakukan sebelum pelaksanaan dilapangan. Jenis pelatihan yang dilakukan diantaranya teknik pengolahan limbah ampas sagu dan hasil, pemasaran serta teknologi pengelolaan limbah rumah tangga. Hal ini penting karena tanpa penyiapan sumberdaya yang memeiliki keterampilan dibidangnya, keberhasilan adalah keniscayaan

Pelaksanaan: pelaksanaan kegiatan dilaksanakan oleh kelompok dengan pengawalan teknologi oleh pengabdi (dosen pengusul) dan pendampingan antara lain oleh penyuluh dan petani andalan. Secara bertahap dalam pelaksanaannya menuju pada pencapaian kemandirian dan peningkatan kesejahteraan. Proses pembuatan ampas sagu sebagai bahan dasar pakan ternak dilakukan secara Fermentasi. Kegiatan pengabdian ini dilakukan untuk meningkatkan pengetahuan para petani ternak di Kelurahan Pentojangan dalam memanfaatkan dan membuat ampas sagu sebagai bahan dasar pakan ternak.

\section{Ketercapaian Target dan Luaran}

Dalam jangka panjang program KKN-PPM ini adalah peningkatan keberdayaan masyarakat melalui peningkatan income perkapita akibat sentuhan pada sektor usaha/ekonomi, peningkatan indeks pembangunan manusia mengingat sentuhan peningkatan pengetahuan dan keterampilan masyarakat di kelurahan pentojangan, pada aspek partisipasi penduduk kelurahan Pentojangan baik pria maupun wanita. Adpun hasil capaian program KKN-PPM yakni antara lain:

- Peningkatan partisipasi dan kinerja produksi pada tingkat masyarakat pengrajin limbah ampas sagu. Perbaikan sistem produksi baik pada lingkup pada teknik dan proses pengolahan pakan ternak sehingga dihasilkan produk yang baik. Perbaikan teknologi melalui penggunaan mesin pencacah, wadah untuk memasak menggunakan biogas sehingga diperoleh efisiensi dan efektivitas proses produksi.

- Indikator ketercapaian target meningkatnya kepedulian dan empati mahasiswa kepada permasalahan masyarakat ekonomi kurang mampu dengan segala permasalahan di dalam masyarakat, sehingga terjadi perubahan perilaku mahasiswa secara signifikan.

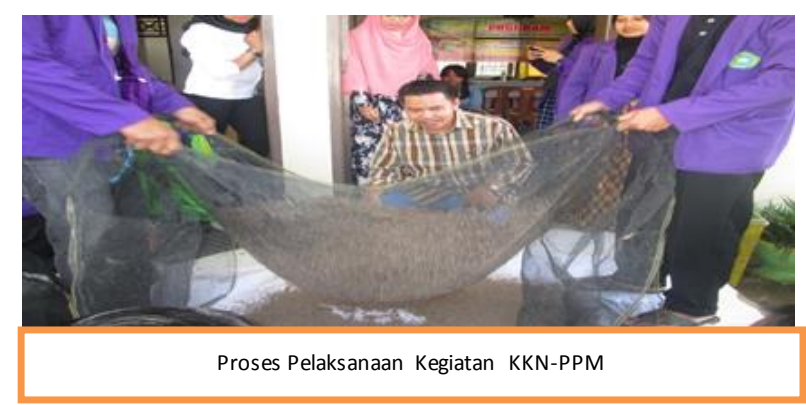

Monitoring dan Evaluasi terhadap kegiatan Program KKN-PPM dilaksanakan untuk mengetahui perkembangan pelaksanaan kegiatan dan menilai kesesuai kegiatan yang telah dilaksanakan dengan perencanaan. Evaluator dapat dibentuk oleh kelompok dan dapat juga berfungsi sebagai motivator bagi pengurus, anggota kelompok dalam meningkatkan pemahaman yang berkaitan dengan pengelolaan sumberdaya yang tersedia dilingkungannya agar berlangsung lestari

\section{SIMPULAN}

Indikator keberhasilan kegiatan KKN-PPM Pemberdayaan Pemanfaatan Limbah Ampas Sagu (Metroxylon Sagu) Sebagai Bahan Dasar Pakan Ternak Unggas Di Kelurahan Pentojangan Palopo, Sulawesi Selatan: kemampuan mahasiswa dalam 
menyelesaikan program yang sudah di tetapkan dan perubahan tercipta dari kondisi sebelumnya dari hasil dalam jangka panjang:

a. Terjadi peningkatan Sumber pendapatan bagi rumahtangga masyarakat penyangga perkotaan;

b. Terjadi transfer ilmu dan teknologi pemanfaatan lahan terbatas yang menghasilkan komoditas pakan ternak bernilai tinggi.

c. Masyarakat dan mitra termotivasi untuk mengembangkan usaha dan kewirausahaan yang berkesinambungan karena memiliki bekal keterampilan dan ilmu dalam mengolah dan memanfaatkan limbah pertanian yang berpotensi ekonomi.

d. Meningkatkan keberdayaan ekonomi dan kesejahteraan mitra dan masyarakat pedesaan pada umumnya.

e. Kenaikan income perkapita masyarakat di Kelurahan Pentojangan Palopo, Sulawesi Selatan

Faktor kunci yang perlu dicermati sebagai simpul kritis untuk keberhasilan dan keberlanjutan KKN-PPM Pemberdayaan Pemanfaatan Limbah Ampas Sagu (Metroxylon Sagu) Sebagai Bahan Dasar Pakan Ternak Unggas Di Kelurahan Pentojangan Palopo, Sulawesi Selatan ini adalah, pertama, para anggota kelompok (petugas lapangan) setempat dan ketua kelompok sejak awal harus dilibatkan secara aktif mulai perencanaan, pelaksanaan, dan evaluasi kegiatan.

Kedua, ketersediaan limbah ampas sagu, penanganan pascapanen dan pengolahan, serta pasar bagi produk yang dihasilkan. Untuk itu, diperlukan penumbuhan dan penguatan kelembagaan usaha pembuatan pakan ternak, dan pemasaran. Selanjutnya, untuk mewujudkan kemandirian kawasan, perlu dilakukan pengaturan pola dan rotasi tanaman sagu termasuk sistem integrase tanaman-ternak.

Ketiga, untuk menuju kemandirian usaha produksi Pakan ternak, diperlukan model usaha secara komersil pada skala industry yang memungkinkan menjadi bentuk badan usaha milik desa (Bumdes) Model ini juga diharapkan dapat memberikan kontribusi pendapatan dan kesejahteraan keluarga.

Keempat, komitmen dan dukungan serta fasilitasi dari pengambil kebijakan utamanya Pemerintah Daerah untuk mendorong implementasi usaha pembuatan pakan ternak berbahan dasar limbah ampas sagu tersebut dalam gerakan secara masif di wilayah kerjanya untuk dilaksanakan secara konsisten merupakan hal penting yang menentukan cepatnya adopsi dan keberlanjutan usaha tersebut.

\section{DAFTAR PUSTAKA}

M., 1977. 'Yield Potential of the Sago Palm, Metroxylon sagu, and its Realization.' In K. Tan (ed.) Sago--76: Papers of the First International Sago Symposium. Kuala Lumpur: Kamajuan Kanji.

Flach, M., 1997. Sago palm. Metroxylon sagu Rottb. Promoting the conservation and use of underutilized and neglected crops. Rome: International Plant Genetic Resources Institute.

Ginting, G.S, 1991. Keterpaduan Ternak Ruminansia dengan Perkebunan, Produksi dan Nilai Nutrisi. Jurnal Penelitian dan Pengembangan Pertanian. Departemen Pertanian. 
Gittinger, James Price. 1986. Analisa ekonomi Proyek-proyek Pertanian, Universitas Indonesia Press. Jakarta.

Khan, M.A., M. Sarwar and M.M.S. Khan. 2004. Feeding value of urea treated corncobs ensiled with or without enzose (corn dextrose) for lactating crossbred cows. Asian-Australia Journal Animimal Science. 8: 1093 - 1097.

Kiston Simanihuruk, A. Chaniago dan J. Sirait. Silase ampas sagu sebagai pakan dasar pada Kambing kacang sedang tumbuh. Seminar Nasional Teknologi Peternakan dan Veteriner 2011. Prosiding.

Kompiang, I.P. 1995. Kumpulan Hasil Penelitian Ternak Unggas dan Aneka Ternak. Balai Penelitian Ternak, Ciawi.

Mirnawati dan G. Ciptaan. 1999. Pemakaian empulur sagu (metroxilon $s p$ ) fermentasi dalam ransum terhadap retensi nitrogen dan rasio efisiensi protein pada ayam Broiler. Jurnal Ilmu Peternakan dan Lingkungan. $5(01): 8-12$.

Nurdin. M. 1995. Pemanfaatan Ampas Sagu Sebagai Subtrat Pembuatan Protein Sel Tunggal. Laporan Hasil Penelitian, Lembaga Penelitian Unhalu. Kendari.

NRC. 1981. Nutrient Requirement of Goats: Angora, Dairy, and Meat Goats in Temperate and Tropical Countries. National Academy Pr., Washington DC.

Nurkurnia, E. 1989. Hasil Fermentasi Rumen Kambing Kacang Betina dengan Pemberian Beberapa Tingkat Ampas Sagu (Metroxylon sp.) dalam Ransum. Skripsi. Fakultas Peternakan Institut Pertanian Bogor, Bogor.

Prastowo, B. 2007. Potensi sektor pertanian sebagai penghasil dan pengguna energy terbarukan. Perspektif 6(2): $84-92$.

Ruddle, K. E. A., 1978. Palm Sago: A Tropical Starch from Marginal Lands. Honolulu: University of Hawaii Press.

Rumalatu. F.J. 1981. Distribusi dan potensi pati beberapa sagu (Metroxylon sp.) di daerah
Seram Barat. Karya Ilmiah. Fakultas Pertanian/Kehutanan yang berafiliasi dengan Fateta IPB, Bogor.

Sapieza, D.A. dan K.K. Bolsen. 1993. Teknologi Silase (Penanaman, Pembuatan dan Pemberiannya pada Ternak). Penerjemah: Martoyondo Rini B.S.

Siri, S., H. Tabioka dan I. Tasaki. 1992. Effec of dietary fibre on utilization of energy and protein in chickens. Poultry Science Journal. 29 : 23-28.

Townsend, P. K., 1977. 'The Cultural Ecology of Sago in New Guinea.' In K. Tan (ed.) Sago76: Papers of the First International Sago Symposium, pp. 91-95.

Trisnowati, 1991. Kecernaan in vitro Ampas Sagu Metroxylon yang Diperlakukan Secara Biologis. Skripsi. Fakultas Peternakan Institut Pertanian Bogor, Bogor.

Uhi, H.T., Usman,. S. Tirajoh, dan B. Tiro. 1997. Pengkajian pemanfaatan pakan ternak potensial di Irian Jaya. Laporan Hasil Pengkajian LPTP Koya Barat, Jayapura.

Harry Tum dan Batsebat Wiro (1999). Pemanfaatan Ampas Sagu (Metroxylon Sagu) Sebagai Pakan Ayam. Seminar Nasional dan Veteriner.

Vyas, V.S, "Some Aspect of Struktural Change in Indian Agriculture," Indian J. Agri. Economics., vol. XXXIV, No. JanuariMaret 1979.

Wahyuni, H.I., I. Mangisah, dan N. Suthama.2008. Pengaruh Pakan Berserat Tinggi dan Probiotik dalam Ransum terhadap Pertumbuhan Organ Pencernaan, Kecernaan Ransum dan Kinerja Itik. Laporan Penelitian Kegiatan A3 Jurusan Nutrisi dan Makanan Ternak. Fakultas Peternakan Universitas Diponegoro, Semarang. 